\title{
Analysis of earth dam failures - A database approach
}

\author{
L. M. Zhang, Y. Xu \\ The Hong Kong University of Science and Technology, HKSAR, China
}

J. S. Jia

The China Institute of Water Resources and Hydropower Research, Beijing, China

\begin{abstract}
A dam may fail when the loading (overtopping flood, flow through or beneath the dam, earthquake or blasting loading, terrorist attacks, deterioration etc.) exceeds the resistance against overtopping, internal erosion, slope instability, sliding/overturning, excessive deformation etc. To properly describe the causes of dam failures, it is necessary to study characteristics of the dams which have experienced failures. In this work, more than 900 dam failure cases throughout the world excluding China are compiled into a database, including details of the dams, the reservoirs, the triggers, and the failures. This paper focuses on failure of earth dams, which makes up $66 \%$ of the whole failure cases in the database. A statistical analysis of the failure characteristics is conducted. According to dam zoning and corewalls, earth dams are divided into four typical categories: (1) homogeneous earthfill dams, (2) zoned earthfill dams, (3) earthfill dams with corewalls, and (4) concrete faced earthfill dams. Further analysis of the failure modes and causes of these subdivided earth dams is carried out. Potential locations at risk are also described to provide the reader with a better understanding of earth dam failures.
\end{abstract}

\section{INTRODUCTION}

In recent years, dam safety draws increasing attention from the public. This is because floods resulting from dam or levee failures can lead to devastating disasters with tremendous loss of life and property, especially in densely populated areas. For instance, the breaching of the levees in New Orleans in August 2005 during Hurricane Katrina caused damage of US\$100-200 billion and a regional death count of about 1600 (Seed et al. 2006). Obviously, analysis of dam failures is of critical importance for disasters prevention and mitigation. Hence, a robust understanding of the characteristics of dam failures (e.g., failure mode, cause, and key influence factors) is needed.

A number of studies have been devoted to investigating dam failures. The International Commission on Large Dams (ICOLD) has reported statistics of dam failures (ICOLD 1995). The United States Committee on Large Dams (USCOLD) has made a survey of incidents, including failures and accidents, to dams in the United States (USCOLD 1988). Many researchers also conducted analyses of dam failures using statistical methods (e.g., Howard 1982; Blind 1983; Silveira 1984; Von Thun 1985; Ingles 1988; Foster et al. 2000). Yet, few attempts have been made to characterize the failure modes and causes for specifically classified earth dams.

In this study, more than 900 dam failure cases throughout the world excluding China are compiled into a database. Totally 593 failure cases on earth dams in the database are utilized to study earth dam failures with a statistical analysis. In the following, earth dams are classified into four major categories: (1) homogeneous earthfill dams, (2) zoned earthfill dams, (3) earthfill dams with corewalls, and (4) concrete faced earthfill dams. Based on the database, the detailed failure modes and causes of these subdivided earth dams are further analyzed. Potential locations at risk are also described to provide the reader with a better understanding of earth dam failures. 


\section{ESTABLISHMENT OF DATABASE}

More than 900 dam failure cases throughout the world excluding China have been collected from the literature (e.g., Vogel 1980; USCOLD 1988; Singh 1996) and compiled into a database. Details of the characteristics of the dams and the failure information are collected. The cases comprise earth dams, concrete dams, masonry dams, rockfill dams, and so on. Fig.1(a) compares the percentages of these types of dams and shows that $66 \%$ of all the cases are earth dams. The failure cases are from over fifty countries, including the US, India, and the UK. Fig.1(b) shows the geographic distribution of the failure cases. The US reported the most amount of cases, about $70 \%$ of the total population. Note that the numbers only reflect how many failure cases are reported, rather than how many failure cases actually occurred. Furthermore, the dam failures in China are compiled in a separate database by the China Institute of Water Resources and Hydropower Research (IWHR) in a cooperative research.

The database has three primary functions: information searching, statistical analysis, and system management for editing and updating. Users may have access to the database via the internet.
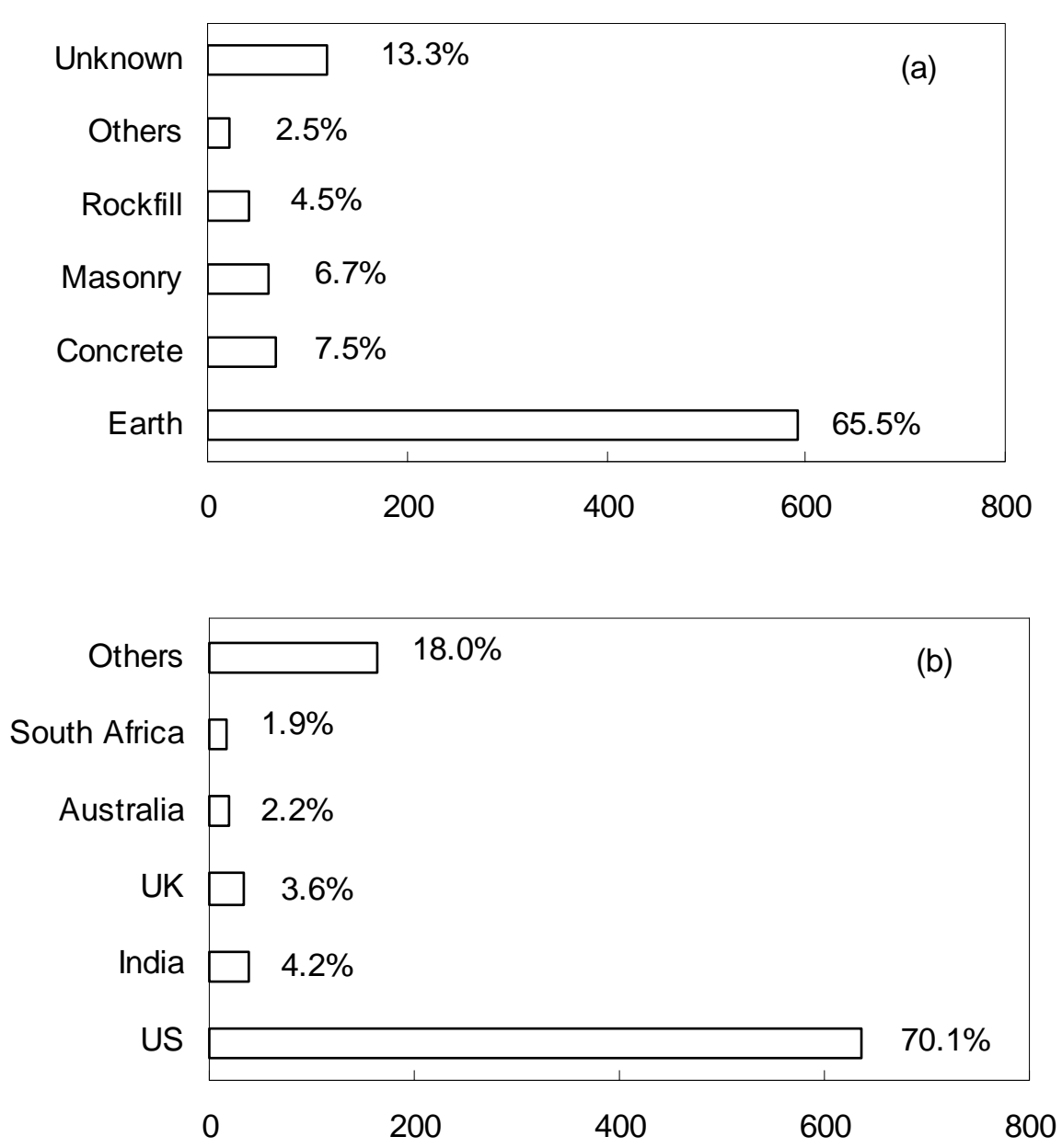

Fig.1 Statistics of (a) dam type and (b) geographic distribution of dam failures

\section{STATISTICS OF EARTH DAM FAILURES}

\subsection{Characteristics of earth dams}

As indicated earlier, 593 cases of earth dam failures are collected. Table 1 shows the reservoir capacities of the failed earth dams. Among the cases with known capacities, most reservoirs have 
capacities less than $1 \times 10^{8} \mathrm{~m}^{3}$. Table 2 shows the heights of the failed earth dams, of which more than half are less than $15 \mathrm{~m}$ high. In other words, a "small" earth dam with either a small reservoir capacity or a small height appears to have a relatively high possibility to fail in the past. Table 3 presents the construction time of the failed earth dams. The dams constructed during two periods, 1890-1939 and 1950-1979, appear to have suffered the highest rate of failure. Table 4 further shows the ages of the earth dams at the time of failure. It is indicated that a dam is most likely to fail within its first five-year service, especially during the first year after construction.

Table 1 Reservoir capacities of the failed earth dams

\begin{tabular}{lll}
\hline Capacity range $\left(\times 10^{6} \mathrm{~m}^{3}\right)$ & Case number & Percentage $(\%)$ \\
\hline$>1000$ & 7 & 1.2 \\
$1000-100$ & 19 & 3.2 \\
$100-10$ & 62 & 10.5 \\
$10-1$ & 63 & 10.6 \\
$<1$ & 96 & 16.2 \\
Unknown & 346 & 58.3 \\
Sum & 593 & 100.0 \\
\hline
\end{tabular}

Table 2 Heights of the failed earth dams

\begin{tabular}{lll}
\hline Height range $(\mathrm{m})$ & Case number & Percentage $(\%)$ \\
\hline$>100$ & 4 & 0.7 \\
$100-60$ & 10 & 1.7 \\
$60-30$ & 44 & 7.4 \\
$30-15$ & 135 & 22.8 \\
$<15$ & 301 & 50.8 \\
Unknown & 99 & 16.6 \\
Sum & 593 & 100.0 \\
\hline
\end{tabular}

Table 3 Construction time of the failed earth dams

\begin{tabular}{lll}
\hline Construction year range & Case number & Percentage (\%) \\
\hline Before 1800 & 8 & 1.3 \\
$1800-1849$ & 11 & 1.9 \\
$1850-1859$ & 8 & 1.3 \\
$1860-1869$ & 14 & 2.4 \\
$1870-1879$ & 5 & 0.8 \\
$1880-1889$ & 21 & 3.5 \\
$1890-1899$ & 32 & 5.4 \\
$1900-1909$ & 38 & 6.4 \\
$1910-1919$ & 50 & 8.4 \\
$1920-1929$ & 41 & 6.9 \\
$1930-1939$ & 31 & 5.2 \\
$1940-1949$ & 22 & 3.7 \\
$1950-1959$ & 38 & 6.4 \\
$1960-1969$ & 53 & 8.9 \\
$1970-1979$ & 36 & 6.1 \\
$1980-1989$ & 9 & 1.5 \\
After 1990 & 2 & 0.3 \\
Unknown & 174 & 29.6 \\
Sum & 593 & 100.0 \\
\hline
\end{tabular}


Table 4 Ages of the earth dams at failure

\begin{tabular}{lll}
\hline Age range & Case number & Percentage (\%) \\
\hline $0-1$ & 85 & 14.3 \\
$1-5$ & 96 & 16.2 \\
$5-10$ & 36 & 6.1 \\
$10-20$ & 62 & 10.5 \\
$20-40$ & 58 & 9.8 \\
$40-60$ & 31 & 5.2 \\
$60-80$ & 16 & 2.7 \\
$80-100$ & 7 & 1.2 \\
$100-150$ & 10 & 1.7 \\
$>150$ & 6 & 1.0 \\
Unknown & 186 & 31.3 \\
Sum & 593 & 100.0 \\
\hline
\end{tabular}

Table 5 Subdivision of failed earth dams in terms of dam type.

\begin{tabular}{lll}
\hline Earth dam type & Case number & Percentage (\%) \\
\hline Homogeneous earthfill & 38 & 6.4 \\
Zoned earthfill & 9 & 1.5 \\
Earthfill with corewall & 12 & 2.0 \\
Faced earthfill & 2 & 0.3 \\
Unknown & 532 & 89.8 \\
Sum & 593 & 100.0 \\
\hline
\end{tabular}

According to dam zoning, the failed earth dams can be further subdivided into four typical categories: (1) homogeneous earthfill dams, (2) zoned earthfill dams, (3) earthfill dams with corewalls, and (4) concrete faced earthfill dams. Fig.2 shows the sketches of the four types of dams. Homogenous earthfill dams are composed almost of the same material throughout the cross section. Zoned earthfill dams are composed of several materials, each for one zone (e.g., Zone A and B consist of two different types of soils in Fig.2(b)). An earthfill dam with a corewall contains earth fills and a low-permeability wall (e.g., clay or concrete), which is often built vertically or inclined towards the upstream of the dam. A concrete faced earthfill dam is composed of earth fills and an impermeable concrete facing on the upstream slope. Table 5 shows the subdivision of the failed earth dams in terms of dam type. It is noted that only 61 cases were reported with known categories.

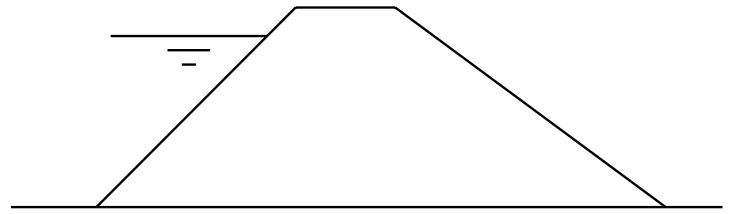

(a) Homogeneous earthfill

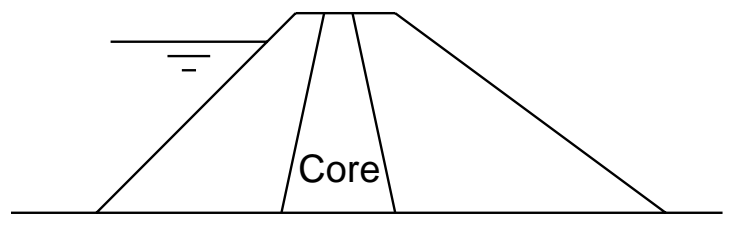

(c) Earthfill with corewall

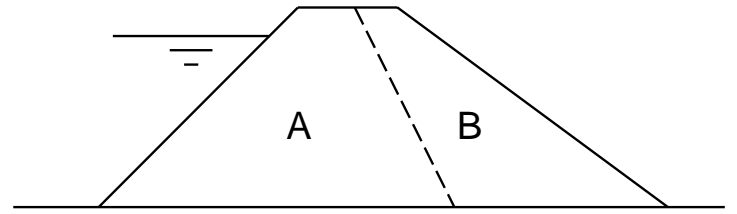

(b) Zoned earthfill

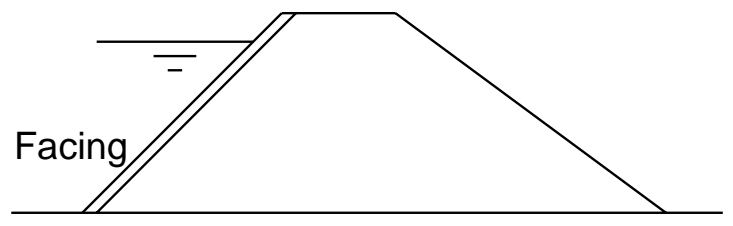

(d) Faced earthfill

Fig.2 Sketches of four typical types of earth dams 


\subsection{Characteristics of dam failures}

Many causes of failure have been identified (e.g. Biswas and Chatterjee 1971; Johnson and Illes 1976; USCOLD 1988). It is difficult to identify a distinct, single cause for a dam failure. Often, several causes are involved in a failure and these causes are interrelated with each other. This study follows almost the same category of failure causes as proposed by the Ministry of Water Resources of the People's Republic of China (MWR 1993). The only difference is that disasters are considered as a typical cause. This is due to that natural disasters and terrorist attacks are likely to become more frequent. Table 6 presents the detailed categories of dam failure causes. Note that "piping" in Table 6 is a general term that describes mechanisms related to seepage.

Fig. 3 shows the percentages of causes for earth dam failures. Most of the cases are caused by either overtopping or quality problems. These two causes led to nearly $80 \%$ of all failure. Fig. 4 shows the percentages of sub-causes of quality problems for earth dam failures. It is clearly seen that $58 \%$ of quality problems are associated with piping in the dam body or foundation. Overall, the most common causes of earth dam failures are overtopping and piping in the dam body or foundation. The principal influence factor on overtopping is insufficiency of spillway capacity. For piping in the dam body or foundation, the most single adverse factor is crack, which can be caused by differential settlement, material shrinkage, foundation defects, and imperfect interface.

Table 6 Categories of dam failure causes (Modified based on MWR 1993)

\begin{tabular}{ll}
\hline No. & Cause \\
\hline 1 & Overtopping \\
1) Insufficient spillway capacity \\
2) extreme flood exceeding design criteria \\
Quality problems \\
1) piping in dam body \\
2) sliding of dam body \\
3) piping in foundation \\
4) piping around spillway \\
5) quality issues in spillway \\
6) piping around culvert and other embedded structures \\
7) quality issues in culvert and other embedded structures \\
Poor management \\
1) decrease of reservoir capacity for flood control due to over storage \\
2) prior to flood season \\
3) temporary heightening of spillway crest not removed in time \\
4) organization issue: nobody responsible for management of dam \\
Disasters \\
1) earthquake \\
2) war and terrorist attack \\
3) breaching of upstream dam \\
4) rodent den \\
Others \\
1) spillway blockage due to bank slide in reservoir \\
2) breach due to excavation on dam for discharging \\
3) poor planning of general layout of project \\
Unknown \\
\hline
\end{tabular}




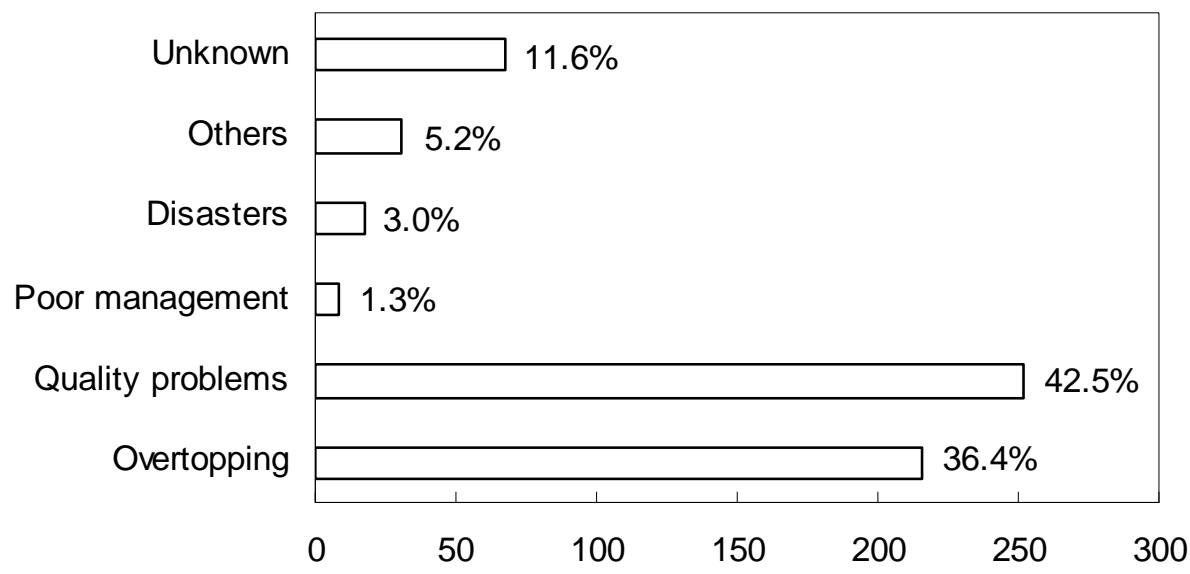

Fig.3 Percentages of causes for earth dam failures

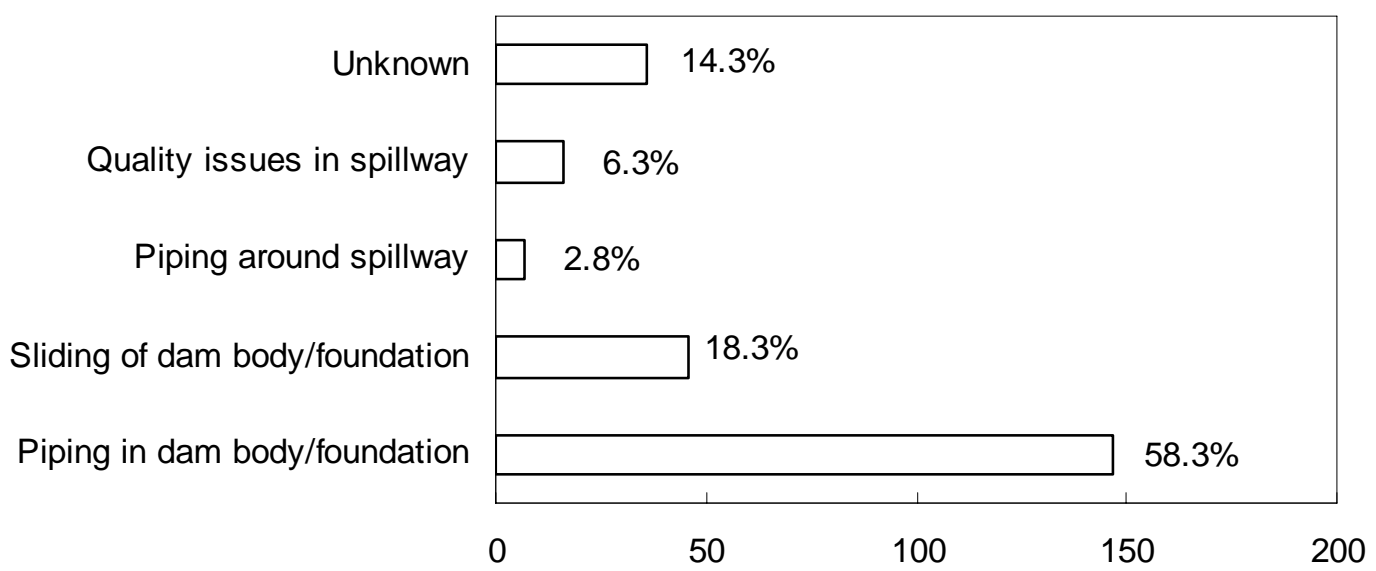

Fig.4 Percentages of sub-causes of quality problems for earth dam failures

\section{ANALYSIS OF SUBDIVIDED EARTH DAMS}

As shown in the previous section, four typical earth dams are considered: (1) homogeneous earthfill dams, (2) zoned earthfill dams, (3) earthfill dams with corewalls, and (4) concrete faced earthfill dams (See Fig.2). Table 7 shows a summary of failure causes for the four types of earth dams based on 61 cases. For homogeneous earthfill dams and zoned earthfill dams, piping in the dam body/ foundation is a dominant failure cause. Besides, overtopping is also identified as an important failure cause. In contrast, for earthfill dams with corewalls, failures are mostly attributed to overtopping. Piping in the dam body/foundation appears to become less important. It is evident from the comparison that the corewall plays a key role in preventing piping in the dam body/foundation.

Table 7 Summary of failure causes for the four typical earth dams (61 cases)

\begin{tabular}{|c|c|c|c|c|c|c|}
\hline Earth dam type & Overtopping & Quality problem & & Poor & Disasters & Sum \\
\hline & & $\begin{array}{l}\text { Piping in dam } \\
\text { body/foundation }\end{array}$ & Others & management & & \\
\hline Homogeneous earthfill & 13 & 22 & 2 & 1 & - & 38 \\
\hline Zoned earthfill & 3 & 6 & - & - & - & 9 \\
\hline Earthfill with corewall & 8 & 2 & 1 & - & 1 & 12 \\
\hline Concrete faced earthfill & - & 2 & - & - & - & 2 \\
\hline
\end{tabular}




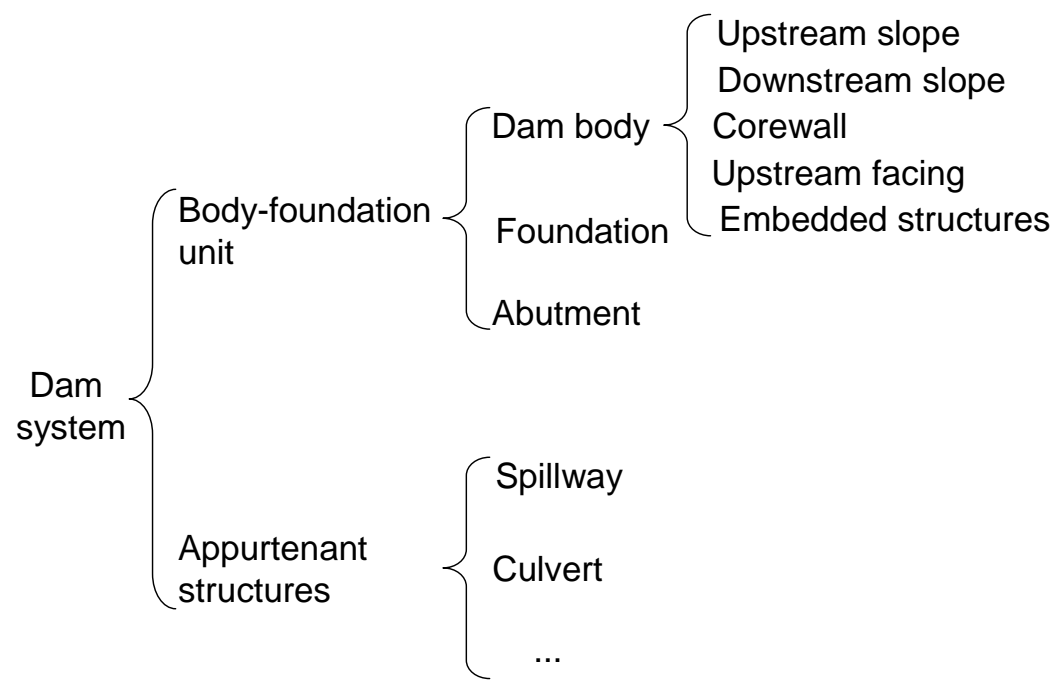

Fig.5 Potential locations at risk in a dam system

One or two layers of filters are usually built on the downstream side of the corewall, which help prevent piping failure in the dam. Due to insufficient data (only 2 cases), no analysis is conducted for concrete faced earthfill dams in this study.

In order to better characterize the failure modes and causes, a dam system can be divided into several parts, called "potential locations at risk", as shown in Fig.5. The two primary failure causes, i.e. overtopping and piping in the dam body/foundation (simplified as "piping" in the later sections for convenience) will be discussed in relation to these potential locations at risk. Homogeneous and zoned earthfill dams are grouped together due to their similar failure causes, as indicated in Table 7.

Two failure cases of earth dams are shown in Fig.6 with Case (a) due to overtopping and Case (b) due to piping. Fig.6(a) shows the Banqiao dam after failure. The dam was built in the early 1950s on the Ru River in Zhumadian Prefecture, Henan Province, China. It was an earthfill dam with a clay corewall, having a maximum height of $24.5 \mathrm{~m}$ and a storage capacity of 492 million $\mathrm{m}^{3}$. It failed due to overtopping during Typhoon Nina on August $8^{\text {th }}$ in1975. Fig.6(b) shows the Baldwin Hills dam during failure. The dam was constructed in 1951. It was a homogeneous earthfill dam $71 \mathrm{~m}$ high and $198 \mathrm{~m}$ long. It failed due to piping after retaining a flood on December 14, 1963.
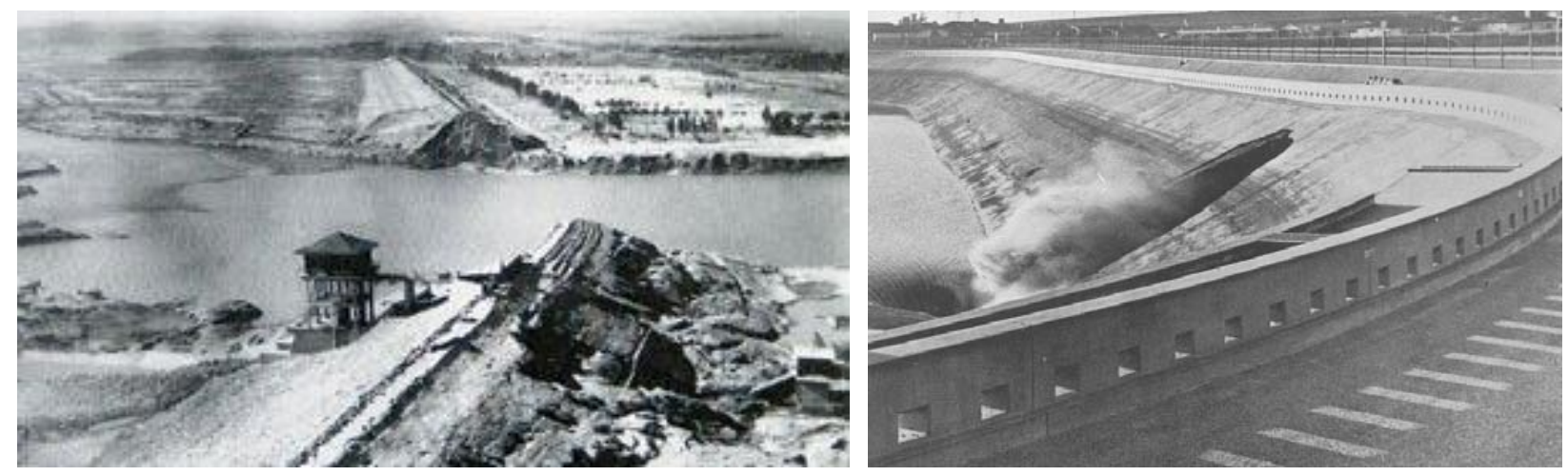

Fig.6 (a) Banqiao dam after failure and (b) Baldwin Hills dam during failure

\subsection{Homogeneous/zoned earthfill dams}

Dam failures due to overtopping often occur in the flood season. As presented before, insufficient spillway capacity is a major reason for overtopping. Therefore, the most important potential location at risk is at the spillway. The foundation may be another potential location at risk. This is due to that the settlement of dam crest reduces the freeboard and the settlement is often attributed to faulty 
foundation. The third potential location at risk is the downstream slope. The erodibility of the downstream slope material is one of the controlling factors for the erosion process over time, and hence determines whether a dam eventually fails or not. In a word, spillway, foundation, and downstream slope are believed to be potential locations at risk, which have great influence on the overtopping-failure of earthfill dams. However, it is of particular interest to find that floods have a more profound influence on the overtopping failure of earthfill dams.

For dam failures due to piping, the impact of inflow floods does not seem to be extremely significant, although floods do increase the possibility of piping occurrence due to larger gradients of seepage flow. Whether piping occurs or not primarily depends on the dam system itself, including the configuration of the dam, the construction quality of the dam, the geologic conditions. Compared to overtopping failure, more potential locations at risk are found for piping failure, which can be any part of the dam body/foundation, as shown in Fig.5. For instance, a faulty foundation can lead to piping failure in several ways. In the first scenario, if the bedrock in the foundation contains faults not adequately treated, an adverse seepage through the foundation can develop. In the second scenario, soft soils in the foundation can lead to differential settlement cracks in the dam body, resulting in piping through the dam body. In the third scenario, weak seams left at the interface between the dam body and the foundation can result in contact seepage along the interface. Any of the above scenarios may be accompanied by the other two. Therefore, it is very difficult to detect the piping paths and stop the seepage completely. To some extent, overtopping is easier to control.

\subsection{Earthfill dams with corewalls}

Failures of earthfill dams with corewalls due to overtopping are similar to that in Section 4.1 for homogeneous/zoned earthfill dams, except at the location of corewall. The corewall often consists of inerodible or less erodible materials, such as masonry, asphalt concrete, or clay. The erosion process of the corewall zone is relatively slow, allowing more time for warning and mitigation of losses, and taking measures to prevent more extensive dam failure.

For dam failures due to piping, appreciable differences exists between homogeneous/zoned earthfill dams and earthfill dams with corewalls. The corewall has a good control of seepage through the dam body; the piping paths are more likely to be associated with the foundation, the abutment, or their interfaces with the dam body. This does not mean that the dam body is absolutely free from piping. Instead, hydraulic fracturing is a common phenomenon that creates preferential flow paths in the clay corewall. As a result, the corewall clays erode as water flows along the hydraulic fractures. It may be concluded that foundation, abutment, or their interfaces with the dam body are noticeable potential locations at risk for earthfill dams with corewalls; while the piping paths may pass through the dam body, due to either hydraulic fracturing of the corewall or poor contact with any embedded structures.

The threat locations at risk for homogeneous/zoned earthfill dams and earthfill dams with corewalls are summarized in Table 8. These potential locations at risk are ranked in two categories: "High risk" and "Low risk". It must be recognized that the classification is somehow judgemental, of which "High" and "Low" are simply based on frequency of occurrence in the failure cases. Note that for earth dams, failure by either overtopping or piping does not occur all of a sudden. The failure process often lasts for a period of time from within one hour to several hours, which gives us a chance to mitigate the losses from the failure.

Table 8 Summary of potential locations at risk for typical types of earth dams

\begin{tabular}{lllll}
\hline Earth dam type & Overtopping & \multicolumn{1}{c}{ Piping } & Low risk \\
\cline { 2 - 5 } & High risk & Low risk & High risk & \\
\hline Homogeneous/zoned & Spillway; & Foundation & Dam body; Foundation; & \\
earthfill & Downstream slope & & Abutment & Dam body \\
Earthfill with corewall & $\begin{array}{l}\text { Spillway; } \\
\text { Downstream slope }\end{array}$ & Foundation; & Foundation; & Abutment \\
\hline
\end{tabular}




\section{FURTHER STUDY}

This paper focuses on qualitative analysis of the failure characteristics of earth dams. To make optimal engineering decisions in practice, a more robust understanding of the influence factors on the safety of the whole system of dams is required. Risk analysis should be conducted for a dam system in further study, including the estimation of probability of failure of the dams, breach flood routing, vulnerability of targets from the flooding, capability of contingency management, and consequences of failures in terms of both economic loss and human casualty. In the risk analysis, the dam failure database can be used as a diagnosis tool to help quickly determine the possible failure modes and causes in a dam system. The Bayesian method may be used to update the probability of failure of the dams by monitoring the conditions of the dynamic dam system.

\section{CONCLUSIONS}

Based on approximately 900 cases of dam failures, a statistical analysis of the failure characteristics has been conducted for earth dams. The modes and causes of failure for carefully classified earth dams, as well as their relation to potential locations at risk, have also been studied. Several features can be observed:

1) The most common causes of earth dam failures are overtopping and piping in the dam body or foundation.

2) For homogeneous earthfill dams and zoned earthfill dams, piping in the dam body/foundation is a dominant failure cause. Overtopping is also identified as an important failure cause.

3) For earthfill dams with corewalls, failures are mostly attributed to overtopping. Piping in the dam body/foundation appears to be less likely.

4) For homogeneous earthfill dams and zoned earthfill dams, spillways, foundations, and downstream slopes are believed to be potential locations at risk for overtopping failure; while any part of the dam body/foundation can be a potential location at risk for piping failure.

5) The overtopping failure of earthfill dams with corewalls is similar to that of homogeneous/zoned earthfill dams, except that the corewall may erode more slowly.

6) For the piping failure of earthfill dams with corewalls, foundations, abutments, or their interfaces with the dam body are noticeable potential locations at risk; the piping paths may still pass through the dam due to either hydraulic fracturing of the corewall or poor contact with the embedded structures.

\section{ACKNOWLEDGMENTS}

This research is substantially supported by a Key Research Project "Study on reservoir dam failure prevention and mitigation" sponsored by the Ministry of Water Resources of the People's Republic of China. The writers would especially like to thank Dr. D.Y. Sun of the China Institute of Water Resources and Hydropower Research (IWHR), for providing much needed information during the preparation of this paper. Invaluable assistance from Messrs. B.S. He and C. Zhao of IWHR is also cordially acknowledged.

\section{REFERENCES}

Biswas, A.K. and Chatterjee, S. (1971) Dam disasters - an assessment. Eng. J. (Canada), 54(3), p.3 -8 .

Blind, H. (1983) The safety of dams. Water Power and Dam Construction, 35(5), p. $17-21$.

Foster, M., Fell, R. and Spannagle, M. (2000). The statistics of embankment dam failures and accidents. Canadian Geotechnical Journal, 37(5), p.1000 - 1024. 
Howard, T.R. (1982) Statistical analysis of embankment dam failure. Proc. 19th Annual Engineering Geology and Soils Engineering Symposium, Pocatello, ID, USA. p.1 - 17.

ICOLD. (1995) Dam failures statistical analysis. International Commission on Large Dams (ICOLD), Bulletin 99.

Ingles, O.G. (1988) A review of dam failure: past, present and future. In Flood insurance and relief in Australia. Edited by D.I. Smith, H. Smith, and J.W. Smith. Australian National University, Canberra. p. $159-167$.

Johnson, F.A. and Illes, P. (1976) A classification of dam failures. Water Power and Dam Construction, 28(12), p. $43-45$.

MWR. (1993) National inventory of reservoir dam failures. The Ministry of Water Resources of the People's Republic of China (MWR), Beijing (in Chinese).

Seed, R.B., Bea, R.G., Abdelmalak, R.I., Athanasopoulos, A.G., Boutwell, G.P., Bray, J.D., Briaud, J.-L., Cheung, C., Cobos-Roa, D., Cohen-Waeber, J., Collins, B.D., Ehrensing, L., Farber, D., Hanemann, M., Harder, L.F., Inkabi, K.S., Kammerer, A.M., Karadeniz, D., Kayen, R.E., Moss, R.E.S., Nicks, J., Nimmala, S., Pestana, J.M., Porter, J., Rhee, K., Riemer, M.F., Roberts, K., Rogers, J.D., Storesund, R., Govindasamy, A.V., Vera-Grunauer, X., Wartman, J.E., Watkins, C.M., Wenk Jr., E., and Yim, S.C. (2006). Investigation of the Performance of the New Orleans Flood Protection Systems in Hurricane Katrina on August 29, 2005. Volume I: Main Text and Executive Summary. National Science Foundation, USA.

Silveira, A. (1984) Statistical analysis of deteriorations and failures of dams. In Safety of dams. Edited by J.L. Serafim. A.A. Balkema, The Netherlands. p. $55-60$.

Singh, V.P. (1996) Dam breach modelling technology. Water Science and Technology Library. Vol. 17. Kluwer Academic Publishers, Boston.

USCOLD. (1988) Lessons from dam incidents, USA II. Committee on Dam Safety of the United States Committee on Large Dams (USCOLD). American Society of Civil Engineering, New York.

Vogel, A. (1980) Bibliography of the history of dam failures (CD Rom). Risk Assessment International, Vienna, Austria.

Von Thun, J.L. (1985) Application of statistical data from dam failures and accidents to risk based decision analysis on existing dams. Internal Report, United States Bureau of Reclamation (USBR), Denver, Colorado. 